\title{
Health Risks of Consuming Untreated Borehole Water from Uzoubi Umuna Orlu, Imo State Nigeria
}

Lele Kelechi Charity ${ }^{1}$, Verla Andrew Wirnkor ${ }^{2}$, Amaobi Collins Emeka ${ }^{2}$, AjeroAdaugo Isioma ${ }^{1}$, Enyoh Christian Ebere ${ }^{2}$ and Verla Evelyn Ngozi $^{3^{\star}}$

${ }^{1}$ Department of Biochemistry, Faculty of Science, Imo State University Owerri, Imo State, Nigeria

${ }^{2}$ Department of Chemistry, Imo State University, Owerri, Imo State, PMB 2000, Nigeria

${ }^{3}$ Department of Environmental Technology, School of Environmental Technology, Federal University of Technology, Owerri, Imo State Nigeria

*Corresponding author: Ngozi VE, Department of Environmental Technology, School of Environmental Technology, Federal University of Technology, Owerri, Imo State Nigeria, Tel: 07069288937; E-mail: verngo@yahoo.com

Received date: October 16, 2018; Accepted date: November 05, 2018; Published date: November 09, 2018

Copyright: (c) 2018 Charity LK, et al. This is an open-access article distributed under the terms of the Creative Commons Attribution License, which permits unrestricted use, distribution, and reproduction in any medium, provided the original author and source are credited.

\begin{abstract}
Water is highly essential for both industrial and human activities, and so scarcity of good drinking water in both rural and urban areas in developing countries is of great concern. Six borehole water samples obtained from twelve different villages in UzoubiUmunaOrlulabeled A-F where collected and investigated for physicochemical characteristics and heavy metals. Result showed that all metals except for Cadmium $(\mathrm{Cd})(0.0492 \mathrm{mg} / \mathrm{L})$, Nickel $(\mathrm{Ni})$ $(0.032 \mathrm{mg} / \mathrm{L})$ and Mercury $(\mathrm{Hg})(0.0018 \mathrm{mg} / \mathrm{L})$ had concentration higher than WHO permissible limit for safe drinking water. All metals exhibited low to moderate contamination factor except for $\mathrm{Ni}(6.0)$ which showed high contamination factor at borehole B, Cd at borehole A (3.6), B (4.2), D (40) and $\mathrm{Hg}(3.0)$ at borehole A. Individual pollution load index for all metals at the different sampled borehole water were low, indicating that the water is unpolluted. Ranking base on decreasing order of mean anthropogenic input, followed the order $\mathrm{Cd}(930 \%)>\mathrm{Ni}$ $(139.2 \%)>\mathrm{Hg}(125 \%)>\mathrm{Cu}(59.33 \%)>\mathrm{Zn}(54.43 \%)>\mathrm{Se}(50.8 \%)>\operatorname{Ag}(49.14 \%)>\operatorname{Ar}(33.33 \%)>\mathrm{Cr}(30.0 \%)>\mathrm{Pb}(24.33 \%)$. $\mathrm{HQ}$ via ingestion for both adult and children follow the decreasing order respectively $\mathrm{Cr}>\mathrm{Pb}>\mathrm{Cu}>\mathrm{Zn}>\mathrm{Cd}>\mathrm{Ni}$; $\mathrm{Ni}>\mathrm{Cr}>\mathrm{Pb}>\mathrm{Cu}>\mathrm{Zn}>\mathrm{Cd}$. HQ via dermal contact for both adult and children follow the decreasing order respectively $\mathrm{Cu}>\mathrm{Zn}>\mathrm{Pb}>\mathrm{Cd}>\mathrm{Cr}>\mathrm{Ni} ; \mathrm{Cr}>\mathrm{Cd}>\mathrm{Zn}>\mathrm{Cu}>\mathrm{Pb}>\mathrm{Ni}$. $\mathrm{HI}$ via ingestion and dermal contact for children $(8.47 \mathrm{E}-04,1.33 \mathrm{E}-03)$ showed that children were more exposed to health dangers when compared to adult for prolong consumption of the borehole water. WQI of the five sampled borehole water were categorized under excellent water quality and follow. Ranking the WQI follows the order; $E>A>D>F>B=C$ respectively. A positive correlation was observed for the borehole water samples confirming anthropogenic input. Though not polluted the investigated boreholes water was found to be contaminated and requires proper treatment before consumption as prolong usage could lead to serious health risk arising from metals bioaccumulation in human body.
\end{abstract}

Keywords: Anthropogenicity; Assessment models; Contamination factor; Hazard quotient; Pollution

\section{Introduction}

Water is a highly essential resource for human and industrial activities. About one third the world population use ground water for drinking [1]. Developing countries tends to face scarcity of good drinking water. An estimated 884 million people in the world especially in developing regions still do not get their drinking water from approved sources [2]. The availability of quality drinking water to all citizens in developing countries (Africa)will serve as the breaking point of poverty alleviation as substantial amounts of national budgets are been used to treat preventable waterborne diseases [3]. The United Nations now recognizes the availability of good drinking water for humans as a human right [4]. An estimated 52 billion cubic meters of ground water component is found in Nigeria, while total replenishable water resource in Nigeria is estimated at 319 billion cubic meters. This indicates that Nigeria has adequate groundwater resources to meet its current water demands. However, only $58 \%$ and $39 \%$ of the inhabitants in urban and rural areas have access to potable water supply respectively [5]. There exists emerging technology for wastewater treatment. One of the pioneer technologies is the membrane bioreactor which is widely used throughout the world. Sepehri and Sarrafzadeh in
2018 tried to enhance the efficiency of the membrane bioreactor through a novel approach. They enriched nitrifiers in the bioreactor and demonstrated that it can mitigate fouling remarkably and enhance the nitrification efficiency.

Heavy metal contamination of ground water is a major environmental problem due to their strong toxicity of some even at low concentration. They tend to cause serious health challenges because of their toxic, persistent and bio-accumulating nature in living tissues [6]. Different studies have shown they are present in borehole water. Elinge et al. [7] assessed the heavy metal concentration in borehole water obtained from three areas in Aliero community of Kebbi State observed that some heavy metals determined were found to have levels above the WHO recommended value while others, such as $\mathrm{Ca}, \mathrm{Mg}, \mathrm{Fe}$ and $\mathrm{Zn}$ had values below the permissible unit. The level of the metals followed the order $\mathrm{Cu}>\mathrm{Pb}>\mathrm{Cr}>\mathrm{Ni}>\mathrm{Co}$. Another Edokpayi et al. [8] research assessed the physio-chemical and heavy metals concentrations in eight randomly selected boreholes water at Muledane village. Results revealed that parameters such as turbidity, nitrate, iron, manganese and chromium in boreholes did not comply with standard South African permissible limits. Multivariate analyses were also carried out and result revealed that the boreholes water sample had both natural and anthropogenic activities as sources of heavy metal contamination. Water quality assessment for groundwater around a municipal waste dumpsite located in Oke-Afa, 
Oshodi/Isolo area of Lagos state showed compared to WHO standard acceptable limits, TDS, chloride and conductivity of some of the samples were higher. High quantities of heavy metals such as Aluminum and Barium were also observed [9-23]. Ground water quality in Owerri west by investigated forty-five water samples from wash boreholes. Results revealed that most boreholes were polluted [24]. The pollution levels of groundwater in parts of Imo River Basin, South Eastern Nigeria [25] revealed that the level of pollution was relatively high in Owerri. Chemometric evaluation of borehole water in Orji, Owerri revealed some bore holes were contaminated by cadmium and the boreholes water was of poor-quality having water quality index (WQI) of 100.5.

This study therefore aims at investigating the concentration of heavy metals from six different untreated bore hole samples obtained from 12 villages within UzoubiUmunaOrlu using both chemometric and quantitative risk assessment models. These include Cf, PLI, An, HQ, HI, CDI and WQI to clearly explain data and interpret measured parameters. This could be assessed in enlightenment of the people around the study area on the use and health risk involve in the consumption of untreated water from borehole sources.

\section{Materials and Methods}

\section{Study area}

UmunaOrlu is situated on a high land area and is bounded by Amaifeke in Orlu L.G.A, Mgbee in Ideato L.G.A, Ebeiri in Umuowa and by Eziachi in Orlu L.G.A at the. North, North east, South east and east respectively. They occupy about 36 kilometers North West of Owerri the state capital. Their source of natural water is obtained from Ogidi stream at Amaifeke in Orlu L.G.A. Umunaorlu is made up of 12 villages according to Orlu L.G.A white paper of September 1999, with population estimated at 54,088 [17].

\section{Sampling and sample pretreatment}

Six different borehole samples were collected from twelve different villages in the same location and labeled A to F. Samples were collected in triplicate using sterile containers from each village and mixed to form a composite of one sample for each two villages. Each of these containers was rinsed thoroughly with the samples [26-41].

\section{Determination of physiochemical parameter}

Parameters such as electrical conductivity, $\mathrm{pH}$, TDS, TSS and temperature $(\mathrm{C})$, of the ground water source were measured in situ. Temperature was measured with thermometer (modal LCD portable digital multi stem of $\left(-50^{\circ} \mathrm{C}\right.$ to $\left.150^{\circ} \mathrm{C}\right)$. Electric conductivity and $\mathrm{pH}$ were measured by Systronic' direct reading conductivity meter (308) and digital $\mathrm{pH}$ meter (HANNA $\mathrm{pH}$ ) respectively. Total dissolved solid (TDS) was measured by digital (Hold) TDS meter. Anions and cations were measured according to APHA method $[6,40]$.

\section{Analytical procedure for heavy metal}

To determine the total metal concentrations, $5 \mathrm{mLs}$ of samples each was first acidified with $10 \mathrm{mLs}$ concentrated aqua regia. The water samples were digested for four hours using $\mathrm{HCl}: \mathrm{HNO}_{3}$ of 1:3. Heavy metal concentration determined using FS 240 Varian Atomic Absorption Spectrophotometer according to Enyoh et al. [10].

\section{Data analysis}

Data were subjected to mean, standard deviation, correlation and single factor ANOVA with $(\mathrm{P}<0.05)$. Chemometric and quantitative health risk analysis were carried out.

\section{Chemometric analysis}

Contamination assessment factor: Contamination factor determines the level of individual contamination of heavy metals in a given sample. It is calculated using the formula below.

$$
\mathrm{Cf}=\mathrm{C}_{\text {metal }} / \mathrm{C}_{\text {background }}
$$

Where Cf represent contamination factor, $\mathrm{C}$ metal represent the concentration of heavy metal and $\mathrm{C}$ background represent the background value of metal. Background values for water sample were taken from (WHO, 2003/2004) [11] guidelines for safe drinking water.

Pollution Load Index (PLI): The pollution load index (PLI) as proposed by Tomlinson et al. [12] is able to estimate the overall metal concentration state in a given sample and gives probable solution to curb the issue [12]. The PLI was used to determine the individual pollution index for the various point of water samples using the formula as stated below.

$$
P L I=n \sqrt{C_{f 1} x C_{f 2} x C_{f 3} x \ldots . . C_{f n}}
$$

Where PLI=Pollution load index, $\mathrm{n}=$ Total number of investigated metals, $C_{f 1}{ }_{f n}=$ Individual contamination factor(3)

Anthropogenicity: Anthropogenicity (APn), measures directly the percentage or extent of anthropogenic input on the influence of metal concentrations in the water.

$$
A P n=\frac{\mu}{C_{\text {background }}} \times 100(4)
$$

The $\mu$ is current or measured concentrations of metals in the water, while $\mathrm{Cb}$ is the background value is considered from world average value in shale $(\mathrm{mg} / \mathrm{kg})$ stated above [13].

Water quality index (WQI): Water quality index was calculated using eight parameters from physiochemical characteristic. WQI is derived and calculated with the formula on equation 5 . WHO standard was used in the calculation of water quality index [37].

$$
W Q I=\frac{\sum_{i=1}^{n} W_{i} q_{i}}{\sum_{i=1}^{n} W_{I}}(5)
$$

where WQI; water quality index, Wi; unit weight and qi; quality rating.

\section{Quantitative health risk assessment}

An individual risk pathway as a result of human exposure to trace metals contamination could be through inhalation via nose and mouth, directing estion and dermal absorption through skin. Dermal absorption and ingestion routes are common exposure pathway for water pollutants. Mathematical methods used to determine human health risk through these two pathways was calculated using Equations below adapted from the US EPA risk assessment guidance for superfund (RAGS) methodology [27,29]. 


$$
E X P_{\text {in }}=\frac{C_{\text {water }} \times I R \times E F \times E D}{B W \times A T} \times 100(6)
$$

where, Expin: exposure dose through ingestion of water $(\mathrm{mg} / \mathrm{kg} /$ day); Expderm: exposure dose through dermal absorption $(\mathrm{mg} / \mathrm{kg} /$ day); Cwater: average concentration of the estimated metals in water $(\mu \mathrm{g} / \mathrm{L})$; IR: ingestion rate is $(2.2 \mathrm{~L} /$ day for adults; $1.8 \mathrm{~L} /$ day for children) obtained from [27]; EF: exposure frequency (365 days/year); ED: exposure duration (70 years for adults; and 6 years for children); BW: average body weight (70 kg for adults; $15 \mathrm{~kg}$ for children); AT: averaging time (365 days/year $\times 70$ years for an adult; 365 days/year $\times$ 6 years for a child); SA: exposed skin area $\left(18,000 \mathrm{~cm}^{2}\right.$ for adults; 6600 $\mathrm{cm}^{2}$ for children); Kp: dermal permeability coefficient in water, $(\mathrm{cm} / \mathrm{h})$, 0.001 for $\mathrm{Cu}, \mathrm{Mn}$, Fe and $\mathrm{Cd}$, while 0.0006 for $\mathrm{Zn}$; 0.002 for $\mathrm{Cr}$ and 0.004 for $\mathrm{Pb}$ and $\mathrm{Ni}$ [34]; ET: exposure time $(0.58 \mathrm{~h} /$ day for adults; 1 $\mathrm{h} /$ day for children) and CF: unit conversion factor $\left(0.001 \mathrm{~L} / \mathrm{cm}^{3}\right)$ [27-29].

Potential non-carcinogenic risks due to exposure to heavy metals were determined by comparing the exposure route with the reference dose (RfD) for the two pathways [27]. Hazard quotient (HQ) toxicity potential was evaluated using the expression equation 7 .

$$
H Q_{\text {in }} / \text { derm }=\frac{E X P_{\text {in }} / \text { derm }}{R f D_{\text {in }} / \text { derm }}(7)
$$

Where RfDin/ dermis ingestion/dermal toxicity reference dose (mg/kg/day). The RfDin and RfDderm values were obtained from the literature $[27-29,31,32] . \mathrm{HQ}<1$ is assumed to be safe and taken as not significant non-carcinogenic [33], but $\mathrm{HQ}$ value $>1$ may be a major potential health concern in association with over exposure of humans to the contaminants. The overall potential non-carcinogenic effects posed by more than one metal and pathway, is obtained by summing the computed HQs across metals and its expressed as hazard index (HI) [27]. HI $>1$ poses health risk [28,30].

$$
H I=\sum_{i=1}^{n} H Q_{\text {in }} / \operatorname{derm}(8)
$$

where HIin/dermis hazard index via ingestion or dermal contact. Chronic daily intake (CDI) of heavy metals through ingestion was calculated using Equation 9;

$$
C D I=C_{\text {water }} \times \frac{D I}{B W}(9)
$$

Where Cwater, DI and BW represent the concentration of trace metal in water in $(\mathrm{mg} / \mathrm{kg})$, average daily intake of water were taken as IR and BW was same in equation 6.

\section{Results and Discussion}

The physiochemical parameters of water are important when it comes to understating its quality. Temperature of drinking water,

\begin{tabular}{|c|c|c|c|c|c|c|c|c|}
\hline Parameters & A & B & C & D & $E$ & $\mathbf{F}$ & NSDWQ, 2007 & WHO 2003/2004 \\
\hline $\operatorname{Temp}\left({ }^{\circ} \mathrm{C}\right)$ & 28 & 28 & 29 & 28 & 29 & 28 & - & $20-30$ \\
\hline $\mathrm{pH}$ & 6.45 & 6.68 & 6.57 & 6.7 & 6.85 & 6.79 & $6.5-8.8$ & $6.5-8.5$ \\
\hline Colour & 4 & 5 & 5 & 4 & 4 & 4 & 0.5 & - \\
\hline $\mathrm{EC}(\mu \mathrm{S} / \mathrm{cm})$ & 262.2 & 27 & 35 & 29.5 & 33 & 36 & 1000 & 100 \\
\hline TDS (mg/l) & 264 & 135 & 152 & 238 & 138 & 138 & 500 & 250 \\
\hline TSS (mg/l) & 2.95 & 4.52 & 7.89 & 9.45 & 6.87 & 5.68 & 50 & 50 \\
\hline Nitrate $(\mathrm{mg} / \mathrm{l})$ & 0.17 & 0.85 & 0.96 & 0.64 & 0.88 & 0.21 & 50 & 50 \\
\hline $\mathrm{SO}_{4}^{2-}(\mathrm{mg} / \mathrm{l})$ & 16.07 & 10.25 & 13.47 & 15.91 & 14.82 & 15.45 & 100 & 100 \\
\hline $\mathrm{Cl}^{-}(\mathrm{mg} / \mathrm{l})$ & 72.65 & 85.2 & 178 & 98 & 267 & 95 & 250 & 250 \\
\hline $\mathrm{Na}^{+}(\mathrm{mg} / \mathrm{l})$ & 17.6 & 10.8 & 210 & 48 & 340 & 195 & 200 & 200 \\
\hline $\mathrm{Mg}^{2+}(\mathrm{mg} / \mathrm{l})$ & 3.2 & 0.89 & 2.7 & 2.06 & 0.86 & 2.6 & 0.2 & - \\
\hline $\mathrm{K}^{+}(\mathrm{mg} / \mathrm{l})$ & 7.3 & 5.2 & 2.8 & 6.8 & 7.8 & 8.5 & - & - \\
\hline $\mathrm{Ca}^{2+}(\mathrm{mg} / \mathrm{l})$ & 12.6 & 17.4 & 26.8 & 22.4 & 22.5 & 10.5 & - & - \\
\hline
\end{tabular}
according to WHO standard ranges between 20-30C. Temperature observed ranged from 28-29C. This was in line with the WHO standard for safe drinking water (Table 1).

Table 1: Physiochemical parameters of water from borehole in UzoubiUmunaOrlu.

$\mathrm{pH}$ values of the observed borehole water ranged from 6.45-6.85. This is in line with the standard for drinking water for both WHO and NSDWQ. Major ions observed were all within WHO standard for safe drinking water $[42,43]$.

Nitrate is the stable form of nitrogen which plays a significant role in the process of eutrophication [44]. It is the final product obtained during the biochemical oxidation of ammonia. It is said to be an indicator of pollution in public water supply [45]. Nitrate in the present study were all below standard when compared to the NSDWQ and WHO standard for safe drinking water. Similar findings except for nitrate in sample BH53 (50.6 mg/L) which showed values higher than the WHO standard for safe drinking water. 
Page 4 of 7

The mean of the six different samples of borehole water where subjected to a single factor ANOVA with $(\mathrm{P}<0.05)$. Result revealed a $\mathrm{P}>0.05$, indicating no significant difference between the sampled points and therefore can be attributed to similar anthropogenic activities around the study area. The concentration of heavy metal in borehole water obtained from UzoubiUmunaOrlu is shown in Table 2 below. The concentration of $\mathrm{Cu}$ in the borehole samples ranged between $0.1-0.8 \mathrm{mg} / \mathrm{l}$ with mean value of $0.47 \mathrm{mg} / \mathrm{l}$ (Table 2).

\begin{tabular}{|c|c|c|c|c|c|c|c|c|}
\hline $\begin{array}{l}\text { Metals } \\
(\mathrm{mg} / \mathrm{L})\end{array}$ & A & B & C & D & $E$ & $\mathbf{F}$ & Mean & WHO 2003/2004 \\
\hline $\mathrm{Cu}$ & $0.23 \pm 0.01$ & $0.8 \pm 0.1$ & $0.1 \pm 0.1$ & $0.7 \pm 0.1$ & $0.6 \pm 0.1$ & $0.23 \pm 0.06$ & 0.443 & 1.0 \\
\hline $\mathrm{Cr}$ & $0 \pm 0.00$ & $0.01 \pm 0.01$ & $0.03 \pm 0.01$ & $0 \pm 0.00$ & $0.04 \pm 0.01$ & $0.01 \pm 0.008$ & 0.014 & 0.05 \\
\hline $\mathrm{Zn}$ & $0.18 \pm 0.01$ & $4.6 \pm 0.2$ & $0.8 \pm 0.1$ & $3.6 \pm 0.2$ & $4 \pm 0.2$ & $3.15 \pm 0.362$ & 2.723 & 5.0 \\
\hline $\mathrm{Ni}$ & $0.01 \pm 0.01$ & $0.12 \pm 0.07$ & $0.02 \pm 0.01$ & $0 \pm 0.01$ & $0.01 \pm 0.01$ & $0.007 \pm 0.0045$ & 0.028 & 0.02 \\
\hline $\mathrm{Pb}$ & $0.02 \pm 0.01$ & $0 \pm 0.00$ & $0.01 \pm 0.01$ & $0 \pm 0.00$ & $0.03 \pm 0.01$ & $0.013 \pm 0.013$ & 0.012 & 0.05 \\
\hline $\mathrm{Hg}$ & $0.006 \pm 0.004$ & $0.002 \pm 0.001$ & $0 \pm 0.00$ & $0 \pm 0.00$ & $0.001 \pm 0.001$ & $0.006 \pm 0.013$ & 0.003 & 0.002 \\
\hline $\mathrm{Se}$ & $0.5 \pm 0.1$ & $0 \pm 0.00$ & $1.1 \pm 0.1$ & $1.73 \pm 0.06$ & $1.64 \pm 0.04$ & $0.283 \pm 0.184$ & 0.876 & 1.72 \\
\hline $\mathrm{Cd}$ & $0.018 \pm 0.013$ & $0.021 \pm 0.003$ & $0.005 \pm 0.001$ & $0.2 \pm 0.001$ & $0.002 \pm 0.001$ & $0.033 \pm 0.013$ & 0.047 & 0.005 \\
\hline $\mathrm{Ag}$ & $0.69 \pm 0.02$ & $0 \pm 0.00$ & $0.53 \pm 0.04$ & $0.2 \pm 0.1$ & $0.7 \pm 0.02$ & $0.003 \pm 0.005$ & 0.354 & 0.72 \\
\hline $\mathrm{Ar}$ & $0 \pm 0.00$ & $0 \pm 0.00$ & $0.01 \pm 0.01$ & $0.01 \pm 0.02$ & $0.01 \pm 0.01$ & $0.00 \pm 0.00$ & 0.005 & 0.01 \\
\hline
\end{tabular}

Table 2: Heavy metal concentration of borehole water obtained from UzoubiUmunaOrlu.

These observed values were found to be within WHO permissible limit for drinking water. Similar findings were observed by Tukura et al. [14]. $\mathrm{Cu}$ is essential to human life but at high concentration can cause chronic anemia, vomiting, diarrhea, nausea, abdominal pain liver and kidney damage, and stomach and intestinal irritation. Copper occurs in drinking water either from copper pipes or additives used in controlling algal growth [15].

Chromium content in the five samples ranged between $0-0.04 \mathrm{mg} / \mathrm{L}$ with mean value of $0.014 \mathrm{mg} / \mathrm{L}$. The concentration of $\mathrm{Cr}$ observed was less than the maximum acceptable standard by WHO. Prolong exposure to Chromium can cause serious damages to the kidney, liver, circulatory and nervous tissue [16]. A study recorded high $\mathrm{Cr}$ in 52 borehole water sources from twelve local governments in Nasarawa State and attributed it to surface contamination originating from anthropogenic and geological sources [14]. Cr concentrations in nature are small and so elevated $\mathrm{Cr}$ in water must be attributed to human activities enriching the water with $\mathrm{Cr}$.

The mean value of $\mathrm{Zn}$ observed was $2.723 \mathrm{mg} / \mathrm{L}$. Amongst all five borehole water samples, samples B was found to be higher than the started WHO standard for safe drinking water. Datuku in Nangodi catchment reported zinc concentrations that ranged from below detection limits to $0.013 \mathrm{mg} / \mathrm{L}$ [18]. Research reported zinc concentration that ranged from 0 to $0.190 \mathrm{mg} / \mathrm{L}$ from surface waters samples in Newmont Ghana gold mining concession areas [19]. Samuel et al. [4] also observed low Zn concentration from his study area. Zinc plays an important role in physiological and metabolic process of many organisms but at high concentration can be very toxic [20].

The concentration of $\mathrm{Ni}$ in the borehole samples ranged between $0-0.12 \mathrm{mg} / \mathrm{L}$ with mean value of $0.028 \mathrm{mg} / \mathrm{L}$. Borehole $\mathrm{B}$ value on $\mathrm{Ni}$ concentration was above the WHO stated limit of $0.02 \mathrm{mg} / \mathrm{L}$. Tukura et al. [14] recorded no $\mathrm{Ni}$ contamination in the borehole samples analyzed. Edokpayi et al. [7] recorded high level of Ni contamination and attributed it to the presence of igneous rocks around the study area [21].

All borehole samples showed $\mathrm{Pb}$ concentration within WHO permissible limit of $0.05 \mathrm{mg} / \mathrm{L}$. In a study Elinge et al. [7] recorded high $\mathrm{Pb}$ concentration in his study. Lead causes damages to the nervous connection most especially in young children and also cause blood and brain disorder [7]. In the current study $\mathrm{Pb}$ was highest at $\mathrm{E}$ $(0.03 \pm 0.01 \mathrm{mg} / \mathrm{L})$. This could be due to increasing awareness of $\mathrm{Pb}$ toxicity and band on pms additives, tetraethyllead (Table 3 ).

Amongst all six samples analyzed the highest level of $\mathrm{Hg}$ was observed in borehole water A $(0.006 \pm 0.004 \mathrm{mg} / \mathrm{L})$. This is higher than the stated WHO permissible limit for safe drinking water. Similar findings were observed in a study made in Ghana [3]. Mercury (Hg) affects the kidney and central nervous system [26].

Se, $\mathrm{Ag}$ and Ar showed values within WHO standard for safe drinking water. $\mathrm{Cd}$ concentration were found to be higher than the WHO standard. Similar findings were observed by Samuel et al. [4] with $\mathrm{Cd}$ exceeding WHO permissible limit for safe drinking water. Cadmium even at low concentration causes adverse health effects such as kidney damage, bronchitis, and osteomalacia. It can also affect the nervous system and enhance the development of cancer [22].

\begin{tabular}{|l|l|l|l|l|l|l|l|}
\hline \multirow{2}{*}{ Metals } & \multicolumn{7}{|c|}{ Contamination factor } \\
\cline { 2 - 8 } & A & B & C & D & E & F & Mean \\
\hline $\mathrm{Cu}$ & 0.23 & 0.8 & 0.1 & 0.7 & 0.6 & 0.23 & 0.443 \\
\hline $\mathrm{Cr}$ & 0.00 & 0.20 & 0.6 & 0.0 & 0.8 & 0.2 & 0.3 \\
\hline $\mathrm{Zn}$ & 0.036 & 0.92 & 0.16 & 0.72 & 0.8 & 0.63 & 0.544 \\
\hline $\mathrm{Ni}$ & 0.5 & 6.0 & 1.0 & 0.0 & 0.5 & 0.35 & 1.392 \\
\hline
\end{tabular}


Citation: Charity LK, Wirnkor VA, Emeka AC, Isioma AA, Ebere CE, et al. (2018) Health Risks of Consuming Untreated Borehole Water from Uzoubi Umuna Orlu, Imo State Nigeria. J Environ Anal Chem 5: 250. doi:10.4172/2380-2391.1000250

Page 5 of 7

\begin{tabular}{|c|c|c|c|c|c|c|c|}
\hline $\mathrm{Pb}$ & 0.4 & 0.0 & 0.2 & 0.0 & 0.6 & 0.26 & 0.243 \\
\hline $\mathrm{Hg}$ & 3.0 & 1.0 & 0.0 & 0.0 & 0.5 & 3.0 & 1.25 \\
\hline $\mathrm{Se}$ & 0.291 & 0.0 & 0.639 & 1.006 & 0.953 & 0.165 & 0.509 \\
\hline $\mathrm{Cd}$ & 3.6 & 4.2 & 1.0 & 40 & 0.4 & 6.6 & 9.3 \\
\hline $\mathrm{Ag}$ & 0.958 & 0.0 & 0.736 & 0.278 & 0.972 & 0.0042 & 0.491 \\
\hline Ar & 0.00 & 0.0 & 1.0 & 1.0 & 0.0 & 0.0 & 0.333 \\
\hline PLI & 0 & 0 & 0 & 0 & 0 & 0 & \\
\hline \multicolumn{8}{|c|}{ Anthropogenicity } \\
\hline $\mathrm{Cu}$ & 23 & 80 & 100 & 70 & 60 & 23 & 59.333 \\
\hline $\mathrm{Cr}$ & 0 & 20 & 60 & 0.0 & 80 & 20 & 30 \\
\hline $\mathrm{Zn}$ & 3.6 & 92 & 16 & 72 & 80 & 63 & 54.433 \\
\hline $\mathrm{Ni}$ & 50 & 600 & 100 & 0.0 & 50 & 35 & 139.167 \\
\hline $\mathrm{Pb}$ & 40 & 0.0 & 20 & 0.0 & 60 & 26 & 24.333 \\
\hline $\mathrm{Hg}$ & 300 & 100 & 0.0 & 0.0 & 50 & 300 & 125 \\
\hline Se & 29.1 & 0.0 & 63.9 & 100 & 95.3 & 16.5 & 50.8 \\
\hline $\mathrm{Cd}$ & 360 & 420 & 100 & 4000 & 40 & 660 & 930 \\
\hline $\mathrm{Ag}$ & 95.8 & 0.0 & 73.6 & 27.8 & 97.2 & 0.42 & 49.137 \\
\hline $\mathrm{Ar}$ & 0.00 & 0.0 & 100 & 100 & 0.0 & 0.0 & 33.333 \\
\hline
\end{tabular}

Table 3: Contamination factor and Anthropogenicity of water from different borehole samples.

Obtained values of contamination factor were categorized as reported [23,41]. Bore hole $\mathrm{A}$ was found to be considerably contaminated with $\mathrm{Hg}$ and $\mathrm{Cd}$. Borehole $\mathrm{B}$ was considerably contaminated with $\mathrm{Ni}$ and $\mathrm{Cd}$. Low to moderate contamination for all metal was observed for Borehole $\mathrm{C}$ and Borehole E. All metals showed low to moderate contamination at Borehole D except for Cd which exhibit very high contamination factor. Cadmium affects the nervous system, causes damage to DNA and the immune system, and enhances the development of cancer. It can also cause other non-cancerous diseases that include loss of sense of smell and taste, fibrosis, upper respiratory diseases, shortness of breath, skeletal effects, lumbago, hypertension, tubular proteinuria, and cardiovascular diseases [22].

The pollution load index for all metals in the different sample boreholes water were generally low, indicating no multi element health implication involve in the consumption of the water for a short while but prolong consumption can cause serious health problems.

Anthropogenicity (APn), was used to measures the percentage or extent of anthropogenic input on the borehole water [42]. $\mathrm{Cu}$ had a high anthropogenic input for borehole B, C, D and E with a very high anthropogenic input at C. Very high anthropogenic input was observed for $\mathrm{Zn}$ at borehole $\mathrm{B}$. No anthropogenic input was observed for $\mathrm{Hg}$ at borehole $\mathrm{C}$ and borehole $\mathrm{D}$. $\mathrm{Ni}$ exhibit very high anthropogenic input at borehole $\mathrm{B}$ and borehole $\mathrm{C}$ while $\mathrm{Ag}$ showed high input at bore hole $\mathrm{A}$, borehole $\mathrm{C}$ and borehole $\mathrm{E}$ with no input at borehole $\mathrm{B}$. The mean value of anthropogenicity for all metals followed the decreasing order $\mathrm{Cd}>\mathrm{Ni}>\mathrm{Hg}>\mathrm{Cu}>\mathrm{Zn}>\mathrm{Se}>\mathrm{Ag}>\mathrm{Ar}>\mathrm{Cr}>\mathrm{Pb}$. The major source of $\mathrm{Cd}$ in borehole water could be from battery charging activities. Being a local environment with no industries the sources of these metals are largely unknown.

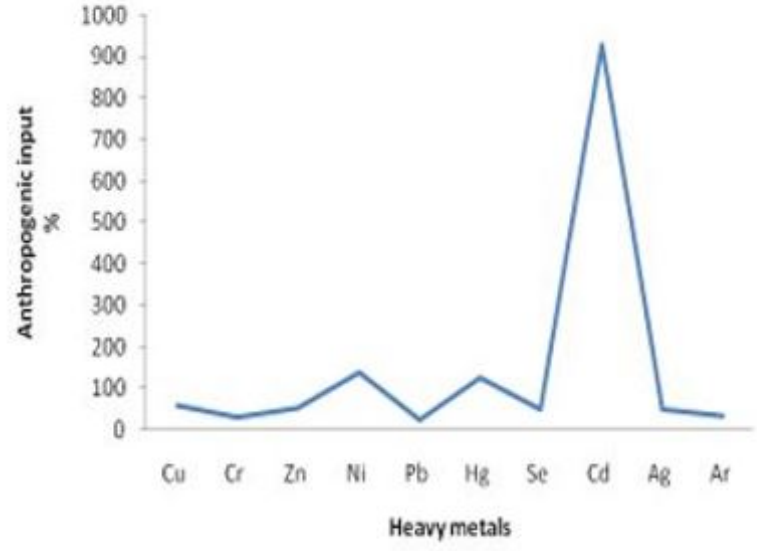

(a)

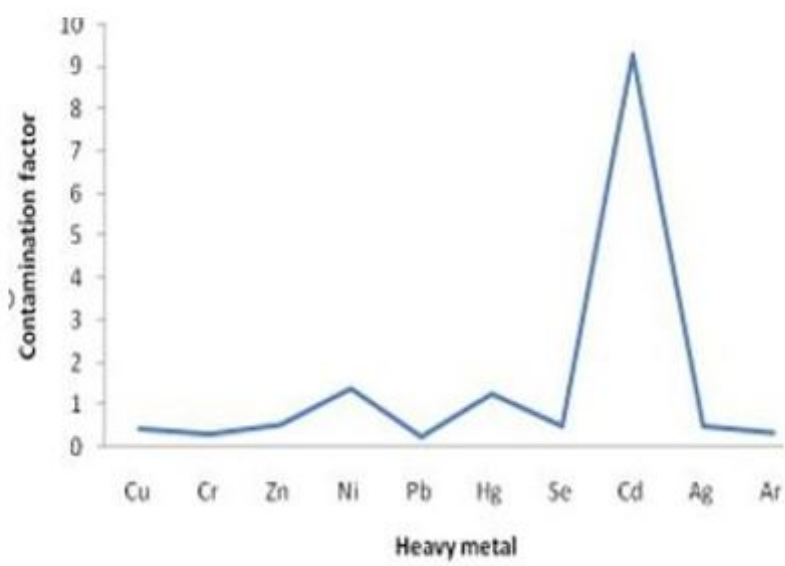

(b)

Figure 1: Line chart of mean value of anthropogenic input 'a' and contamination factor ' $b$ ' of individual metals in the borehole samples.

Both models represented graphically exhibited similar trend indicating high level of Cd contamination. Highest mean APn value for Cd was above $900 \%$. This alarming value can only be attributed to human activity impact (Figure 1). It was Cd again with highest mean contamination factor above 9. Both APn and Cf for all other metals were with acceptable limits except for $\mathrm{Ni}$. 


\section{Water quality index}

Classification of water quality index was done according to Yogendra and Puttaiah [38]. WQI is a single mathematical equation that reduces data obtained from various water quality parameters to single numeric values which represents the quality of the water [39]. The computed WQI is presented in Figure 2. All sampled borehole water could be categorized under excellent water quality.

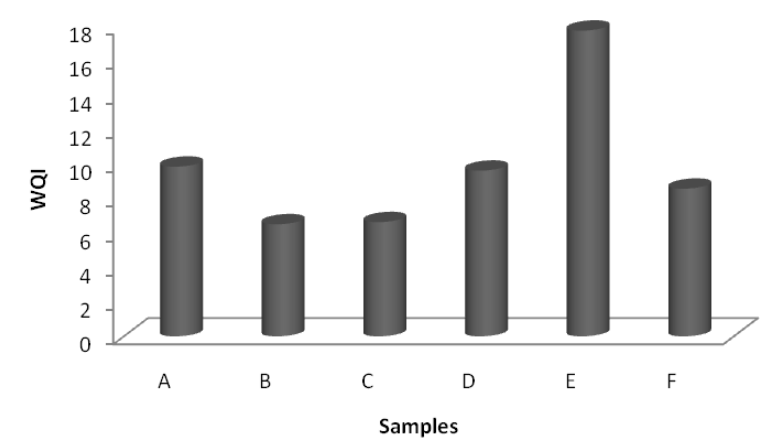

Figure 2: Computed water quality index for borehole water samples.

Comparing the WQI the highest was recorded in sample $\mathrm{E}$ while the least was jointly recorded in samples $B$ and $C$. Ranking the WQI follows the order; $\mathrm{E}>\mathrm{A}>\mathrm{D}>\mathrm{F}>\mathrm{B}=\mathrm{C}$ respectively.

\section{Human risk assessment}

The mean values of metals $\mathrm{Cu}, \mathrm{Cr}, \mathrm{Zn}, \mathrm{Ni}, \mathrm{Pb}$ and $\mathrm{Cd}$ from the five different boreholes obtained from UzoubiUmunaOrlu were subjected to health risk assessment model by the US. EPA, these suggests the health risks that heavy metals could pose on human via direct ingestion and dermal absorption of groundwater (Table 4).

\begin{tabular}{|l|l|l|l|l|l|}
\hline \multirow{2}{*}{ Metals } & \multicolumn{4}{|l|}{ HQin } & \multicolumn{2}{l|}{ HQderm } & CDlin \\
\cline { 2 - 6 } & Adult & Children & Adult & Children & \\
\hline $\mathrm{Cu}$ & $3.83 \mathrm{E}-04$ & $1.46 \mathrm{E}-05$ & $2.14 \mathrm{E}-04$ & $2.68 \mathrm{E}-05$ & $1.53 \mathrm{E}-02$ \\
\hline $\mathrm{Cr}$ & $1.67 \mathrm{E}-04$ & $6.4 \mathrm{E}-04$ & $2.82 \mathrm{E}-05$ & $3.75 \mathrm{E}-04$ & $5.02 \mathrm{E}-04$ \\
\hline $\mathrm{Zn}$ & $2.76 \mathrm{E}-05$ & $1.05 \mathrm{E}-06$ & $6.96 \mathrm{E}-04$ & $1.16 \mathrm{E}-05$ & $8.28 \mathrm{E}-02$ \\
\hline $\mathrm{Ni}$ & $5.0 \mathrm{E}-05$ & $1.74 \mathrm{E}-04$ & $5.63 \mathrm{E}-06$ & $1.04 \mathrm{E}-06$ & $1.00 \mathrm{E}-03$ \\
\hline $\mathrm{Pb}$ & $2.86 \mathrm{E}-04$ & $1.03 \mathrm{E}-05$ & $2.11 \mathrm{E}-05$ & $5.02 \mathrm{E}-05$ & $3.77 \mathrm{E}-04$ \\
\hline $\mathrm{Cd}$ & $3.1 \mathrm{E}-05$ & $7.34 \mathrm{E}-06$ & $2.17 \mathrm{E}-05$ & $8.66 \mathrm{E}-04$ & $1.54 \mathrm{E}-03$ \\
\hline $\mathrm{HI}=$ & $9.45 \mathrm{E}-04$ & $8.47 \mathrm{E}-04$ & $9.87 \mathrm{E}-04$ & $1.33 \mathrm{E}-03$ & - \\
\hline
\end{tabular}

Table 4: Estimated Hazard quotient and overall health index.

The hazard quotient through injection of water HQ in from UzoubiUmunaOrlu for the metals were $<1$ for both adults and children which indicates that these metals could pose minimum hazard to local residents. The HQ derm values were also found to be $<1$ which indicates that dermal adsorption of the metals may have little or no health threat. Health hazard indices (HI) on exposure to the ground water through ingestion and dermal contacts for both adult and children were less than unity. Therefore, from the results observed, the values were below the safe limit of unity which clearly indicates that there was no cumulative potential of adverse risk in water sampled via direct ingestion or dermal absorption to the inhabitants. The chronic risk assessment (CDI) for the metals in the groundwater samples through the ingestion pathway is given in Table 5. Generally, health risk assessment indices like $\mathrm{HQ}$, CDI and the overall non-carcinogenic health risk assessment (HI) when less than unity indicates less significant risk through the ingestion route or dermal contact $[34,35]$. Similar findings were observed by Sheetal and Sudan [36] with health risk assessment indices $<1$ (Table 5).

\begin{tabular}{|l|l|l|l|l|l|l|}
\hline & A & B & C & D & E & F \\
\hline A & 1 & - & - & - & - & - \\
\hline B & 0.029 & 1 & - & - & - & - \\
\hline C & 0.735 & 0.442 & 1 & - & - & - \\
\hline D & 0.291 & 0.89 & 0.771 & 1 & - & - \\
\hline E & 0.356 & 0.906 & 0.78 & 0.987 & 1 & - \\
\hline F & 0.068 & 0.989 & 0.529 & 0.926 & 0.941 & 1 \\
\hline
\end{tabular}

Table 5: Correlation of different sampled borehole water with respect to heavy metal contaminant.

All six borehole samples showed positive correlation coefficient for heavy metals. This could suggest same for source of metals at various villages. Human activity is the major culprit for elevated metals in most rural and urban water sources.

\section{Conclusion}

The investigated borehole water sample were found to be contaminated with $\mathrm{Cd}, \mathrm{Ni}$ and $\mathrm{Hg}$. Contamination factors follow similar trend in terms of metal contamination, while PLI index models confirmed that the water from the different sampled borehole were unpolluted. The mean anthropogenic input for the sampled borehole for the individual metals followed the order $\mathrm{Cd}>$ $\mathrm{Ni}>\mathrm{Hg}>\mathrm{Cu}>\mathrm{Ag}>\mathrm{Se}>\mathrm{Zn}>\mathrm{Ar}>\mathrm{Cr}>\mathrm{Pb}$. It can be seen from the trend that high anthropogenic input was recorded for $\mathrm{Cd}, \mathrm{Ni}$ and $\mathrm{Hg}$. Health risk assessment models HQ, HI, CDI were all less than unity. WQI of the borehole water was categorize into excellent water quality. The present study therefore recommend that the borehole water should be properly treated before consumption to avoid health risk resulting from the high metal contamination in the prolonged use of borehole water from Ozoubi, UmunaOrlu.

\section{References}

1. Nickson RT, McArthur JM, Shrestha B, Kyaw-Myint TO, Lowry D (2005) Arsenic and other drinking water quality issues, Muzaffargarh District, Pakistan. Appl Geochem 20: 55-68.

2. WHO/UNCEF (2010) Progress on sanitation and drinking-water: Joint Monitoring Programme 2010 update.

3. Cobbina SJ, Michael K, Salifu L, Duwiejua AB (2013) Rainwater quality assessment in the Tamale municipality. Int J Sci Technol Res 2: 1-10.

4. Samuel JC, Abudu BD, Reginald Q, Samuel O, Noel B (2015) Comparative assessment of heavy metals in drinking water sources in two 
small-scale mining communities in northern Ghana. Int J Environ Res Public Health 12: 10620-10634.

5. World Health Organization (2006) Meeting the MDG drinking-water and sanitation target. The urban and rural challenge of the decade.

6. Verla AW, Verla EN, Amaobi CE, Enyoh CE (2018) Water pollution scenario at river uramurukwa flowing through owerri metropolis, Imo state, Nigeria. International Journal of Advanced Scientific Research 3: 40-46.

7. Elinge CM, Itodo AU, Peni IJ, Birnin-Yauri UA, Mbongo AN (2011) Assessment of heavy metals concentrations in bore-hole waters in Aliero community of Kebbi State. Advances in Applied Science Research 2: 279-282.

8. Edokpayi JN, Enitan AM, Mutileni N, Odiyo JO (2018) Evaluation of water quality and human risk assessment due to heavy metals in groundwater around Muledane area of Vhembe District, Limpopo Province, South Africa. Chem Cent J 12: 2-16.

9. Kayode OT, Okagbue HI, Achuka JA (2018) Water quality assessment for groundwater around a municipal waste dumpsite. Data Brief 17: 579-587.

10. Enyoh CE, Ihionu EA, Verla AW, Ebosie NP (2016) Physicochemical Properties of Palm Oil and Soil from Ihube Community, Okigwe, Imo State, Nigeria. International Letters of Natural Sciences 62: 35-43.

11. WHO (2006) Guidelines for drinking-water quality [electronic resource]: incorporating first addendum. Vol. 1, Recommendations, 3rd ed.

12. Tomlinson DL, Wilson JG, Harris CR, Jeffrey DW (1980) Problems in the assessment of heavy metal levels in estuaries and the formation of a pollution index. HelgolaenderMeeresunter 33: 566-575.

13. Evelyn VN, Horsfall M, Spiff AI (2015) Physico chemical Characterization of Playgrounds Soils of public Schools in Owerri Metropolis, Imo State, Nigeria. International Journal of Innovation and Applied Studies 13: 472-480.

14. Tukura MI, Ayinya G, Ibrahim IG, Onche EU (2014) Assessment of Heavy Metals in Ground Water from Nasarawa State, Middle Belt, Nigeria. American Chemical Science Journal 4: 798-812.

15. Njar GN, Iwara AI., Offiong RA, Deekor TD (2012) Assessment of Heavy Metal Status Of Boreholes In Calabar South Local Government Area, Cross River State, Nigeria. Ethiopian Journal of Environmental Studies and Management 5: 86-91.

16. Izuchukwu IF, Ozims SJ, Agu GC, Obeagu EI, Onu I, et al. (2016) Knowledge of preventive measures and management of HIV/AIDS victims among parents in UmunaOrlu community of Imo state Nigeria.

17. Cobbina SJ, Myilla M, Michael K (2013) Small scale gold mining and heavy metal pollution: Assessment of drinking water sources in Datuku in the Talensi-Nabdam District. Int J Sci Technol Res 2: 96-100.

18. Asamoah-Boateng EK (2009) Physico-chemical and Microbiological Quality of Surface Waters within the Newmont Ghana Gold Mining Concession Areas. Master's Thesis, Kwame Nkrumah University of Science and Technology (KNUST), Kumasi, Ghana, pp: 50-52.

19. Ferner DJ (2001) Toxicity, heavy metals. eMed J 2: 1.

20. Alloway BJ (1990) Heavy metals in soils. John Wiley and Sons, Inc New York, USA, p: 46.

21. Young RA (2014) Toxicity Summary for Cadmium, Risk Assessment Information System (RAIS). Available online: ais.ornl.gov/tox/profiles/ cadmium.shtml (accessed on 19 October).

22. Nweke MO, Ukpai SN (2016) Use of Enrichment, Ecological Risk and Contamination Factors with Geoaccumulation Indexes to Evaluate Heavy Metal Contents in the Soils around Ameka Mining Area, South of Abakaliki, Nigeria. Journal of Geography, Environment and Earth Science International 5: 1-13.

23. Ijeh IB, Udoinyang IE (2014) Assessment of Groundwater Quality in Selected Areas in Imo State in South Eastern Nigeria. Journal of environment and Earth science 5: 715-722.

24. Ijeh BI, Onu NN (2013) Assessment of pollution levels of groundwater in parts of Imo River Basin, South Eastern Nigeria. International Journal of Water Resources and Environmental Engineering 5: 194-202.
25. Nigerian industrial standard (2007) Nigeria standard for drinking water, $\mathrm{p}: 17$.

26. USEPA (1989) Risk assessment guidance for superfund, vol 1, human health evaluation manual (part A), Report EPA/540/1-89/002, United States Environmental Protection Agency, Washington, USA

27. Li SY, Zhang QF (2010) Spatial characterization of dissolved trace elements and heavy metals in the upper Han River (China) using multivariate statistical techniques. J Hazard Mater 176: 579-588.

28. Asare-Donkor NK, Boadu TA, Adimado AA (2016) Evaluation of groundwater and surface water quality and human risk assessment for trace metals in human settlements around the Bosomtwe Crater Lake in Ghana. Springer Plus 5: 1812.

29. Naveedullah MZH, Yu C, Shen H, Duan D, Shen C, et al. (2014) Concentration and human health risk assessment of selected heavy metals in surface water of the siling reservoir watershed in Zhejiang Province, China. Pol J Environ Stud 23: 801-811.

30. Wu B, Zhao DY, Jia HY, Zhang Y, Zhang XX, et al. (2009) Preliminary risk assessment of trace metal pollution in surface water from Yangtze River in Nanjing Section, China. Bull Environ ContamToxicol 82: 405-409.

31. Iqbal J, Shah MH (2013) Health risk assessment of metals in surface water from freshwater source lakes Pakistan. Hum Ecol Risk Assess Inter J 19: 1530-1543.

32. USEPA (2009) Drinking water standards and health advisories, EPA 822R-09-011. Office of water, Washington, DC, USA.

33. Moore JW, Ramamoorthy S (1984) Trace metals in natural waters. Applied monitoring and impact assessment. New York: Springer, pp: $1-260$.

34. Zhao DYB, Jia HY, Zhang Y, Zhang XX, Cheng SP (2009) Preliminary risk assessment of trace metal pollution in surface water from Yangtze River in Nanjing section, China. Bull Environ ContamToxicol, 82: 405-409.

35. Asare-Donkor NK, Boadu TA, Adimado AA (2016) Evaluation of groundwater and surface water quality and human risk assessment for trace metals in human settlements around the Bosomtwe Crater Lake in Ghana, Springer plus 5: 1812.

36. Sheetal N, Sudan SM (2017) Water quality assessment of Rajsamand Lake, Rajasthan, India. International Research Journal of Environmental Science 6: 22-28.

37. Chatterjee C, Raziuddin M (2002) Determination of Water Quality Index (WQI) of a degraded river in Asansol industrial area (West Bengal). Nature Environ and Poll Tech 1: 181-189.

38. Yogendra K, Puttaiah ET (2008) Determination of water quality index and suitablility of an urban waterbody in shimoga town, Karnataka. Proceedings of Taal 2007: The 12th World Lake Conference, pp: 342-346.

39. APHA (1989) Standard methods for the examination of water and waste water. American Public Health Association, Washington, DC, USA.

40. Enyoh CE, Verla AW, Egejuru NJ (2018) pH Variations and Chemometric Assessment of Borehole Water in Orji, Owerri Imo State, Nigeria. Journal of Environmental Analytical Chemistry 5: 1-9.

41. Verla EN, Verla AW, Enyoh CE (2017) Pollution Assessment Models Of Soils In Portharcourt City, Rivers State, Nigeria. World News of Natural Sciences (WNOFNS) 12: 1-23.

42. Sepehri A, Sarrafzadeh MH (2018) Effect of nitrifiers community on fouling mitigation and nitrification efficiency in a membrane bioreactor. Chemical Engineering and Processing Process Intensification 128: 10-18.

43. Sharma V, Verma BK, Sharma MS (2012) Zooplanktonic and fish fauna of lake Pichhola in relation to its trophic status. J Environ Sci Comp Sci and Eng and Tech 1: 301-310.

44. Offodile ME (2002) Ground Water Study and Development in Nigeria. Mecon Geology and Eng, pp: 303-332.

45. Ijeh BI, Onu NN (2013) Assessment of pollution levels of groundwater in parts of Imo River Basin, South Eastern Nigeria, International Journal of Water Resources and Environmental Engineering 5: 194-202. 